\section{Abstractions}

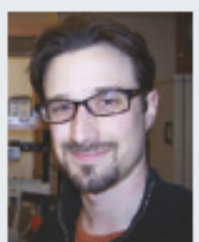

\section{FIRST AUTHOR}

Benjamin Kerr, a biologist

at the University of

Washington, Seattle, sees

migration as a double-

edged sword. Relocation

can help organisms

survive. But if the migrants

are careless with their consumption of

resources, they could ruin their new home.

Kerr examined the dynamics that sustain

or destroy a community by using a robot

to migrate Escherichia coli bacteria (the

hosts) and its viral pathogen (T4 coliphage)

to different neighbourhoods with varying

characteristics. He saw two kinds of phage

behaviour, 'rapacious' and 'prudent'. Kerr

explained to Nature what this might mean.

Why did you come up with the terms rapacious and prudent?

They were a bit more colourful than unrestrained and restrained. What comes to mind when people think of rapaciousness is eating, which is appropriate here, because the phage, in a sense, eat $E$. coli. As an an alogy, think of two different ways of eating abag of crisps. You could prudently pick out crisps one at a time and consume every last carbohydrate. Alternatively, you can shake the inverted bag over your mouth, capturing a few crisps, but wasting a bunch on the floor. In our experiment, the crisps are the E. coli hosts, the snacker is the phage, and we find both prudent and rapacious eating styles.

Why did you use the phrase "tragedy of the commons' in the paper's title?

The term relates to an analogy about shared pasture for grazinglivestock (the commons). Although there are incentives for each herdsman to continue grazing cows, lack of restraint by everyone leads to overgrazing the 'tragedy of the commons'. In our system, as rapacious phage displace prudentusers of bacteria, the phage population becomes less productive.

Did you get along well with your ro bot? Unlike for most of my home electronics, I did read themanual (alearn-by-doing strategy being abit more risky when the machine costs several hundred thousand dollars). Although that got our relationship off on the right foot, the robot did require my constant attention. Actually, I became quite fond of it - especially when it was behaving itself.

What does this study say about migration? The big picture is that while the tragedy of the commons may be inevitable on a local scale, migration can determine whether local tragedies become global tragedies. Different migratory patterns can either liberate or isolaterapacious types. If isolated, unrestrained subpopulations will be shortlived, with relatively prudent resource users left in the long run.

\section{MAKING THE PAPER}

Paul Segall

\section{How tracking a volcano's behaviour led to insight on silent earthquakes.}

The network of GPS (global positioning system) stations set up around a Hawaiian volcano in 1996 was designed to track a very noisy phenomenon. The geophysicists working with the system wanted to see how the land moved when the Kilauea volcano rumbled. They wanted to use such data to help them understand volcanic processes and to predict future eruptions.

As far as these noisy events are concerned, their work was a success. But, as the paper on page 71 of this issue reveals, that wasn't all that the team encountered. Their data also provided an unexpected insight into a much quieter phenomenon: 'silent slips.' These are earthquakes that usually occur when one tectonic plate slides very slowly under another.

Silent slips were first recorded in 1998, but weren't really labelled as such until 2000 , says Paul Segall, a geophysicist at Stanford University who helped set up and run the Kilauea GPS network. "When we set up this network, no one knew about these," says Segall. "Slow earthquakes hadn't yet been discovered." And even after they were discovered, they weren't well understood and were not associated with volcanoes. So Segall didn't expect to see or hear any signs of them in Hawaii.

But Segall's graduate student, Peter Cervelli, saw 'steps' in the data, indicating that slight, sudden movements had taken place. ${ }^{\alpha} \mathrm{He}$ first thought it was a mistake," says Segall. "But after working on it and working on it, he realized it was real and looked like an earthquake." To add to the mystery, no earthquake had been recorded or categorized for the time period that matched the steps.

The team was receiving batches of data every 24 hours. When these were broken down into minutes and seconds, the researchers saw evidence that the land around the volcano's crater

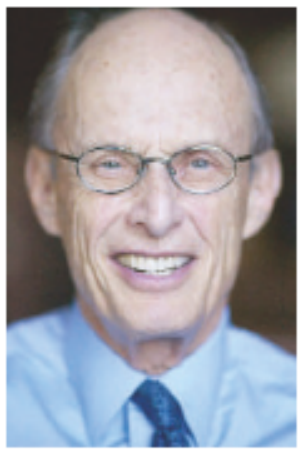

was slowly slipping and sliding, causing small, low-frequency events that set off little earthquakes. This was unusual, as previous silent earthquakes had been associated with the movement of tectonic plates. The Kilauea events, they concluded, were caused by the slippage of land around the volcano's cone.

"These observations occurred very serendipitously," says Segall. "We had no particular hypothesis to test, although we did have particular goals in mind."

There had been some earlier evidence that Kilauea's activity was triggering other events. "We knew from previous measurements that there is a steady sliding of the volcano towards the ocean," explains Segall. This slippage had been linked to earlier earthquakes, such as a major event in 1975 , and there had been speculation that the slippage had helped to generate tsunamis. The latest data should offer a fresh perspective on the volcano's influence, Segall says.

But getting a clearer picture of Kilauea's silent phenomena might prove difficult. It was costly putting up the 20 or so GPS receivers around Kilauea, not to mention the technology to transmit and process the data. The team will almost certainly need more GPS instruments, and would like to have data transmitted more frequently than once a day. Other instruments, such as seismometers and tilt meters, should also help the researchers capture aspects of the silent earthquakes. But much of Kilauea is a national park, so it might be difficult to secure permission to install these devices. Nevertheless, Segall is optimistic that new technology will eventually provide a clearer view of the silent slips. "We keep getting new tools for measuring things," he says. "When we put them out we are see things we never expected."

\title{
QUANTIFIED FUTURES
}

A numerical per spective on Futures, Nature's sciencefictioncolumn.

To celebrate themillennium, Nature launched Futures, a series of science-fiction 'short-shorts'. The first series ran from November 1999 to December 2000, and was revived in February 2005.

At World Con in 2005, the European Science Fiction Society awarded Nature the accolade of 'Best Science Fiction Publis her', but nobody has dared to say to our face that everything Nature publishes is science fiction. Futures authorship varies from well-known SF writers to scientists to peopletrying their hand at fiction for the very first time.

This week's story, 'Semi-autonomous' by Jim Kling appears on page 108.
132 SF stories have been published by Nature since 1999.

11 is the age of Futures' youngest author, Ashley Pellegrino (Nature 439, 890, 2006).

15 is the number of stories written by Nature editors and other NPG staff.

850-950 words is the typical length of a Futures story. "Writing a work of fiction in such a confined space is much harder than itsounds" says editor Henry Gee. 